\title{
Proteomic identification and expression of oral apparatus constituents in cell regeneration of giant ciliate Stentor coeruleus (strain WHEL)
}

Jie Xiong ( $\square$ xiongjie@ihb.ac.cn )

Institute of Hydrobiology Chinese Academy of Sciences https://orcid.org/0000-0001-8923-0424

\section{Wei Wei}

Institute of Hydrobiology Chinese Academy of Sciences

Chuanqi Jiang

Institute of Hydrobiology Chinese Academy of Sciences

Wentao Yang

Institute of Hydrobiology Chinese Academy of Sciences

Wei Miao

Institute of Hydrobiology Chinese Academy of Sciences

Research article

Keywords: Ciliate, Oral apparatus, Proteome, Regeneration, Transcriptome

Posted Date: August 28th, 2019

DOl: https://doi.org/10.21203/rs.2.12053/v1

License: (c) (i) This work is licensed under a Creative Commons Attribution 4.0 International License.

Read Full License 


\section{Abstract}

Background The giant ciliate Stentor coeruleus is a suitable model organism for studying morphogenesis and regeneration at the single-cell level. The anterior end of the cell is dominated by thousands of cilia organized into a ciliated band of membranelles, known as the oral apparatus (OA). This feeding organelle can be induced to shed by urea treatment. The OA then regenerates via a series of defined morphological events and the cell resumes normal feeding activity. These defined events provide an ideal opportunity to identify the protein constituents of $O A$ and their expression patterns in $O A$ regeneration. Results We identified OA constituents in S. coeruleus by mass spectrometry. A total of $882 \mathrm{OA}$-associated proteins were identified; the homologs of 181 of these are known OA constituents in other organisms. The expression pattern of $\mathrm{OA}$-associated genes during regeneration was investigated using single-cell transcriptome sequencing. The expression of most OA-associated genes was high during regeneration, indicating their stable expression after OA shedding. We also identified OA-associated differentially expressed genes that may be involved in regulating $O A$ reconstruction. This information enabled us to hypothesize the architecture of OA of S. coeruleus WHEL. Conclusions We have identified protein components of the $\mathrm{OA}$ and determined the temporal changes in their expression during $\mathrm{OA}$ regeneration in S. coeruleus WHEL. Although our results are preliminary, they form the basis of further studies into the molecular mechanisms of OA development in S. coeruleus. In addition, as S. coeruleus is an important model organism for studying morphogenesis, our findings may help to improve the understanding of OA formation in ciliates.

\section{Background}

Stentor is considered a good system for studying regeneration in protozoa because of its large size and amenability to surgical manipulation [1]. In particular, it can be studied on regeneration as a single cell (structural unit of life) without the need to consider the influence of surrounding cells [2]. In 1885, Gruber firstly found Stentor can be cut into three pieces, each of which could develop into new individuality, and he described in detail the regeneration process of a trisected Stentor cell [3,4]. Several years later, Balbiani reported a series of fundamental biological processes in the same organism, including wound healing, holdfast development, and nuclear behavior during regeneration $[5,6]$.

In Stentor, the process of regeneration includes (i) regeneration of the oral apparatus (OA) and its requirements; (ii) regeneration of the holdfast; and (iii) reconstitution of the normal shape [1]. Of these, OA regeneration is the most attractive and amazing regeneration paradigm. The $O A$ is dominated structure on the anterior end of the cell, consisting of thousands of centrioles and cilia [7] organized into a ciliated band of membranelles. The membranellar band encircles the broad end of the cell body and terminates inside the buccal cavity or gullet $[8,9]$. However, the protein constituents of OA and their spatiotemporal expression patterns in OA regeneration are unknown.

Stentor coeruleus is a very large ciliate that measures $0.5-2 \mathrm{~mm}$ when fully extended. Each cell ciliate is blue to blue-green in color and contains a macronucleus that resembles a string of beads. S. coeruleus is 
a filter feeder that uses its OA to sweep other living cells into its mouth. The feeding apparatus comprises a frontal field, a cytostome and cytopharynx region, and the ciliated membranellar band. Sucrose or urea shock can cause the OA to shed [10]. Thereafter, a new OA regenerates within $8 \mathrm{~h}$ via a series of wellcharacterized morphological stages [11]. These defined stages provide an ideal opportunity to identify the protein constituents of $\mathrm{OA}$ and their expression patterns in $\mathrm{OA}$ regeneration.

Here, we identified the protein constituents of OA in S. coeruleus using mass spectrometry and investigated the expression features of OA-associated genes using single-cell RNA-sequencing (RNASeq). The results provide new insights to the molecular basis of OA in $S$. coeruleus.

\section{Results}

\section{OA-associated proteins of S. coeruleus identified by mass spectrometry}

A total of 882 proteins were identified in extracts from the shed OA of $S$. coeruleus WHEL (note that some may be partial protein sequences because of incomplete transcript assembly). We divided these into three groups: (1) components of different organelles; (2) known OA proteins; and (3) other proteins.

The OA proteome contained 264 proteins associated with components of organelles including mitochondria, ribosomes, vesicles, endoplasmic reticulum, Golgi apparatus, peroxisomes, and centrosomes (Supplementary Table 1). Of these, 149 proteins (57\%) were classified as mitochondrionassociated proteins based on in silico annotation. Although we cannot fully exclude the possibility of contamination, the high number of mitochondrial components identified by mass spectrometry data indicates that there may be a lot of mitochondria associated with the OA. In flagellated protozoa or mammalian sperm, mitochondria are reported to be concentrated around the base of the flagella [20]. Hence, it is possible that mitochondria located near the base of the cilia produce the ATP required to drive ciliary movement in the OA of $S$. coeruleus WHEL [21].

The second group of proteins were homologs of known OA-associated proteins reported in other organisms: this group included molecular chaperone, calmodulin (CaM), adenosine triphosphatase (ATPase), microtubule, guanosine triphosphatase (GTPase), serine/threonine-protein kinase, microfilament, vacuolar protein sorting 4 (VPS4), translation elongation factor 1-a (EF-1a), and intermediate filament (Table 1). Microtubules, microfilaments, and intermediate filaments are associated not only with the eukaryotic cytoskeleton but also with cilia or basal bodies. Ciliary axoneme is a microtubule-based cytoskeleton inside cilia. In Tetrahymena, OA membranelles are connected by microtubules, passing from one membranelle to another, establishing connections between the proximal ends of basal bodies. Near each basal body is a small fibrous ring, the structure of which is maintained by the microfilaments alone [22]. In total we found 35 associated proteins function as aforementioned proteins that were identified in the OA of $S$. coeruleus WHEL. Therefore, it is speculated that the Stentor $\mathrm{OA}$ as a cortical feeding structure is composed of ciliated and non-ciliated basal bodies interconnected by a framework of microtubules and filaments, similar to in Tetrahymena [23]. In addition, different classes of molecular chaperones have been reported in the cilia of diverse organisms: heat shock protein (Hsp) 
70 and Hsp90 have been detected in the cilia [24] and Hsp60 in the basal bodies [25] of Tetrahymena, and Hsp40 (containing a DnaJ domain) and the TCP-1/CCTa subunit of the cytosolic chaperonin CCT (chaperonin containing TCP-1) in cilia have been identified in sea urchin embryos $[26,27]$. We identified a broad group of 40 molecular chaperones in the OA in S. coeruleus WHEL. Of these, Hsp82 (a member of the Hsp90 family) and one or more of Hsp70 family members were associated with both soluble tubulin and tubulin assembled into microtubules in the cilia and cell cortex of Tetrahymena [24]. Hsp60, a mitochondrial chaperone involved in folding of mitochondrial proteins, binds to citrate synthase $/ 14 \mathrm{~nm}$ filaments (intermediate filaments) and is believed to help form the OA in protozoa [25]. Moreover, Hsp40 is a component of the radial spoke complex in sperm flagella of the ascidian Ciona intestinalis, where it may be involved in interactions between the radial spoke and central microtubules [28,29]. TCP-1/CCTa has also been detected in centrosomes, indicating that it may assist in microtubule nucleation [30]. These results demonstrate that chaperones are widely distributed ciliary and flagellar components [27]. In addition, $\mathrm{Ca}^{2+} / \mathrm{CaM}$ signaling is reported to be closely associated with ciliary motility [31]. Further studies showed that $\mathrm{CaM}$ is localized to axonemal microtubules and that $\mathrm{EF}-1 \mathrm{a}$ is a $\mathrm{Ca}^{2+} / \mathrm{CaM}$-binding protein that regulates the actin cytoskeleton in cilia $[25,32,33]$. Serine/threonine-protein kinase 1 is hypothesized to control the growth of cilia in Tetrahymena. In ciliates, the cytostome engages in phagocytosis, which is used as a means of feeding and provides part or all of their nourishment. In phagocytosis, vesicle formation is essential for consuming food via the $O A$ and for transporting proteins between organelles. The VPS4 protein contains highly conserved AAA-ATPase domains; its homologs have been implicated in vesicle formation in yeast and may play a similar role in Tetrahymena [34]. Notably, all of these proteins were shown to localize to the OA in Tetrahymena [31,34,35], and CaM, EF-1a, VPS4, and serine/threonine-protein kinase were identified as known OA proteins in the OA of $S$. coeruleus WHEL. Some proteins likely to be associated with the phagosome and vesicular transport were also identified in the OA of S. coeruleus WHEL. These include three subunits of the vacuolar ATPase and members of the Rab family of small GTPases in Tetrahymena thermophila [36]. Rab proteins are also associated with ERto-Golgi transportation [37]. Our finding indicate that these protein components might be conserved elements of the $\mathrm{OA}$ of ciliates.

Proteins in the third group (neither organellar or known homologs of OA constituents) contained transmembrane helix or structural motifs or were involved in proteolysis, transcription/translation, signaling, amino acid metabolism, fatty acid metabolism, glycolysis/gluconeogenesis, or ubiquitination (Table 2). Phobius [38] or TMHMM [39] software predicted a total of 33 membrane proteins (i.e. containing at least one transmembrane helix) which were annotated as enzymes, transports, and channel proteins. These might either interact with or form part of OA membranes. We also identified 75 proteins containing structural motifs, especially Armadillo, HEAT, leucine-rich repeat, and WD40 repeat, which are known to be involved in protein-protein interactions. Thus, these proteins may be structural components of the OA. In addition, we identified seven ubiquitination related proteins. The same structural motifcontaining proteins and ubiquitin family proteins have also been identified in the $O A$ and are associated with the basal body or centriole in Tetrahymena [40]. 


\section{Overall expression patterns of OA-associated proteins during regeneration}

The OA can be induced to shed by urea shock [10], after which a new OA regenerates over a time course of $9 \mathrm{~h}$ via a series of well-characterized morphological stages (detailed in Fig. 1a) [1,11]. After approximately $1.5 \mathrm{~h}$, a cortical primordium appears as a simple zone of basal bodies growth (Fig. $1 \mathrm{a}$, 1.5h). The primordium then lengthens and forms new ciliary membranelles that grow from a mass of basal bodies in the primordial region (Fig. 1a, 3h-6h). Finally, the entire structure migrates to the anterior end of the cell, considering the position previously held by the shocked organelles (Fig. 1a, 8h-9h). Commensurate with the final cortical changes, the macronucleus coalesced into two large nodes (Fig. 1a, $6 \mathrm{~h}$ ) and then re-nodulates to complete the OA regeneration (Fig. 1a, 8h) [13].

To analyze the associated changes in gene expression, single-cell RNA-Seq was performed at $0.5,1.5,3$, $4,6,8$, and $9 \mathrm{~h}$ after urea shock. Compared with the control cell, 3223 transcript fragments were upregulated and 3061 were downregulated (with at least four fold change (FC) in expression in at least one time point) during regeneration. The results of $\mathrm{GO}$ enrichment analysis were similar to those previously reported in a single-cell RNA-Seq study of another $S$. coeruleus strainPranidhi Sood and collegues; Supplementary Table 2), indicating that our single-cell RNA-Seq data is reliable.

As a previous single-cell RNA-Seq study of $S$. coeruleus gave comprehensive results for differentially expressed genes (DEGs) in regeneration [11], our main focus was on determining changes in the expression of the genes encoding OA-associated proteins that we had identified by mass spectrometry. We first found that the expression level was generally higher for OA proteins than for non-OA proteins (Fig. 1b). This result indicates that $\mathrm{OA}$-associated proteins play a vital role in $\mathrm{OA}$ regeneration. Using the 4FC cut-off, differential expressed OA proteins were identified at each time point during the regeneration process. We found that only a small fraction of OA proteins was up- or downregulated at each time point: the expression of $>83 \%$ OA-associated genes were unchanged compared with the control cell (Fig. 1c). Together with the high level of expression of OA-associated proteins, this result indicates that most OAassociated genes are stably expressed, similar to housekeeping genes.

\section{Differentially expressed OA-associated proteins during regeneration}

The expression of $232(29 \%)$ OA-associated genes changed in at least one time point during regeneration: 44 were upregulated and 188 were downregulated. The expression profiles of all 232 DEGs were clustered by calculating the Z-score of fragments per kilo base of transcript sequence per million base pairs sequenced (FPKM) (Fig. 2). In general, three groups of OA-associated DEGs were identified.

Group 1 contains 44 upregulated genes that showed maximum expression at a single stage of OA regeneration (Table 3): 13 genes were maximally expressed at $0.5 \mathrm{~h}$, eight at $1.5 \mathrm{~h}$, two at $3 \mathrm{~h}$, five at $4 \mathrm{~h}$, nine at $6 \mathrm{~h}$, two at $8 \mathrm{~h}$, and five at $9 \mathrm{~h}$. Several genes that may be important in OA regeneration were found. Expression of cilia/flagella-associated protein 20 (CFA20; SCOERU6382613) peaked at 3 h. CFA20 
is a cilium/flagellum-specific protein involved in axonemal structure organization and motility in Paramecium [41] and Chlamydomonas [42], and functions in regulating cilia size and morphology [43]. Expression of this gene corresponded with a major morphologically feature: appearance of the first cilia. Two Gas2-related domain (SCOERU6109121, SCOERU5478902) containing proteins with microtubulebinding and stabilizing activity [44] and five CaM proteins (SCOERU5237302, SCOERU2832411, SCOERU5679902, SCOERU2839501, SCOERU5228401) with ciliary motility activity [31] reached a peak of expression at the 6-8 $\mathrm{h}$ timepoint of OA formation. The selective stabilization of microtubules has been proposed as the basis of cytoplasmic asymmetry during morphogenesis [45]. In most cases, posttranslationally modified tubulin is found to accumulate within relatively stable microtubules in eukaryotes. Tubulin polyglycylation is the final post-translationally modification to take place during Drosophilia spermatogenesis and its occurrence corresponds to the end of spermatozoan maturation, and may function in axoneme motility [46]. Cilia can bend as the microtubules slide past one another. The arrangement of cilia permits their coordinated movement in response to cytoplasmic signals [47]. Based on these reports, we speculate that group 1 genes may be involved in ciliary maturity and migration in the rebuilt $\mathrm{OA}$.

Group 2 contains 40 genes (Table 4) that were significantly downregulated during the initial stages of OA regeneration but increased expression during the ciliary biogenesis stage of OA regeneration (from $3 \mathrm{~h}$ to $6 \mathrm{~h}$ ). Upregulation of these genes during this stage suggests that they are vital for cilia growth and membranellar band formation in the OA. Some promising candidates that may have important roles in this process were identified. Five HSP genes were identified: three Hsp70 (SCOERU6199801, SCOERU6807002, SCOERU5535901) and two Hsp90 (SCOERU6611202, SCOERU6824901) genes. Homologs of these HSP genes were reported to be involved in microtubule assembly and were associated with actin family forming microfilaments [24]. Four TCP-1/CCTa genes (SCOERU6653011, SCOERU6653002, SCOERU6525301, SCOERU6273502) were identified that may be involved in microtubule nucleation [30]. We also identified a CaM (SCOERU6088901) associated that may be involved in centriole replication and EF-1a (SCOERU6661701), which regulates the actin cytoskeleton in cilia $[25,32,33]$. In addition, three tubulin genes (SCOERU6841701, SCOERU6841712, SCOERU6507601), two actin genes (SCOERU6773301, SCOERU6773311), and two intermediate filament genes (SCOERU6558001, SCOERU6230702), which are components of cytoskeletal filaments, were also identified.

Group 3 contains 148 genes that were downregulated at crucial stages in ciliary biogenesis during OA regeneration (from $3 \mathrm{~h}$ to $6 \mathrm{~h}$ ). These mainly encode enzymes related to metabolism, mitochondria, and proteolysis. This result suggests that the energy for $\mathrm{OA}$ formation is provided by reducing the metabolic process associated with normal growth.

\section{Discussions}

In this study, we investigated the OA proteome of $S$. coeruleus WHEL and identified 882 OA-associated proteins. This result helps us to understand the OA structure. We also investigated the expression 
patterns of OA-associated genes using single-cell RNA-Seq and found that most OA-associated genes do not show significant changes in expression during regeneration. It means that removal of OA does not interrupt the expression of these genes, indicates that most of the materials required to rebuild the OA are already available, which ensures its rapid reconstruction after injury and the rapid resumption of feeding activity. We also identified a large number of DEGs during regeneration. In particular, some DEGs that are upregulated during $\mathrm{OA}$ formation are potential candidate regulators of $\mathrm{OA}$ regeneration.

The ciliate $S$. coeruleus consists of a complex oral band composed of thousands of long cilia organized into structures called membranelles. These form the membranellar band, which can be induced to shed by urea treatment (Fig. 3a). In 1955 Fauré-Fremiet and Rouiller discovered that each membranelle is composed of two short, parallel rows of the ciliary basal body, which are connected to each other laterally and give off ciliary rootlets into the cell interior. The whole basal structure of the membranelle extends for about $20 \mu \mathrm{m}$ into the endoplasm (Fig. 3b) $[48,1]$. Our findings suggest that $S$. coeruleus WHEL has a similar OA that includes cilium and subcellular structures (Fig. 3c). As show in figure 3c, the centrosome is a primary organelle that servers as the main microtubule organizing center in the animal cells, as well as a regulator of cell progression [49]. In addition, centrioles, which are core centrosomal components, have another distinct function as basal bodies. Centriole biogenesis is required for formation of the basal body. After the basal body is formed, it migrates to the cell surface and docks onto the actin-rich cortex. Next, the basal body nucleates an outgrowth of axonemal microtubules, which protrude beneath an extension of the membrane to give rise to the cilium. After this, continued elongation of the cilium requires the selective import and transport of ciliary proteins to the tip mediated by intraflagellar transport (IFT) proteins, such as IFT20 and IFT54. These two proteins are involved in vesicle transport from the Golgi apparatus to cilia $[50,51]$. The movement of IFT proteins along microtubules is catalyzed by dynein and kinesin motor proteins. Ciliogenesis also requires the transport of membrane proteins to construct the ciliary membrane [52]. The ribosomal, endoplasmic reticulum, vesiclar, and Golgi apparatus proteins identified in the OA proteome might also be associated with forming the OA structure. The main function of mitochondria and peroxisomes is to produce the energy required for cellular metabolism. Based on our findings, we propose that the cilium is an indispensable structure, and underneath subcellular structures are essential for OA maintenance and regeneration in S. coeruleus.

\section{Conclusions}

In this study, we have identified protein components of the OA and determined the temporal changes in their expression during OA regeneration in S. coeruleus WHEL. This information enabled us to hypothesize the architecture of OA of $S$. coeruleus WHEL. Although our results are preliminary, they form the basis of further studies into the molecular mechanisms of OA development in S. coeruleus. In addition, as $S$. coeruleus is an important model organism for studying morphogenesis, our findings may help to improve the understanding of OA formation in ciliates.

\section{Methods}




\section{Cell isolation, cultivation and species identification}

S. coeruleus cells were isolated from freshwater samples taken from East Lake (N30³2'52"; E114²1'7"), Wuhan, China in October 2014. Cells were maintained in culture at $20^{\circ} \mathrm{C}$ in Modified Stentor Medium (MSM) in the dark [2], supplementing the Chlorogonium elongatum in moderation as living prey. The $S$. coeruleus $18 \mathrm{~S}$ small subunit (SSU) ribosomal RNA genewas PCR amplified using the universal ciliate primer pair. The gene shared $99 \%$ sequence identity with the 18S SSU rRNA gene sequence of $S$. coeruleus isolate WM001, previously reported by Slabodnick et al. (GenBank accession: MPUH01002597) [12]. However, the assembled transcriptomes using RNA-Seq data show relatively low sequence identity to the genome of $S$. coeruleus isolate WM001 (GenBank accession: MPUH00000000). These results suggest that the strain isolated in this study was not identical to the WM001 strain, the genome of which has been sequenced; thus, we named the isolated strain $S$. coeruleus WHEL.

\section{Induction of regeneration and sample collection}

For sample collection, $30 \mathrm{ml}$ cultures of $S$. coeruleus WHELcells were grown at $20^{\circ} \mathrm{C}$ to obtain about 300 cells. All experiments were performed using cells from cultures that had been starved for several days because observation of macronuclear nodes is facilitated by the absence of food vacuoles in the cytoplasm. Before urea shock, a single cell was collected as a control cell (Fig. 4a). To induce regeneration, cells were incubated for $1 \mathrm{~min}$ in a 4\% urea solution (shown in Fig. 4b) [10]. This treatment caused the membranellar bands to be sloughed from the cells, followed by replacement of the entire complement of feeding organelles [13]. After urea treatment, cells were washed in cold MSM, centrifuged at 3,200rpm for $30 \mathrm{~s}$ at $4^{\circ} \mathrm{C}$, and resuspended in fresh MSM. On the one hand, we picked up a large number of shedding OA distinguished from the cortex subfractions by mouth pipette using a Zeiss anatomical lens (Fig. 4c). On the other hand, we collected populations of somatic cells (without OA) and placed them in normal culture conditions for OA regeneration (Fig. 4d). Regeneration proceeds through a series of characteristic morphological changes involving both the cell cortex and macronucleus. With the development of their morphology, we isolated a single cell from the cell populations at each of the following time in regeneration process: $0.5,1.5,3,4,6,8$, and $9 \mathrm{~h}$. In total, eight cells were isolated per treatment: one control cell and seven cells at different times of the regeneration process. Each cell was placed in a $0.2 \mathrm{ml}$ thin-walled PCR tube containing $2 \mu \mathrm{l}$ of cell lysis buffer $(0.2 \%$ (vol/vol) Triton X-100 and $2 \mathrm{U} / \mu \mathrm{l}$ RNase inhibitor). The $\mathrm{OA}$ and cell samples were snap frozen and stored at $-80^{\circ} \mathrm{C}$ until use.

\section{Single-cell RNA-Seq}

Total eight single-cells were amplified using Smart-Seq2 (SMARTer Ultra Low RNA kit (Art. No. 634936, Clontech, USA) (for Illumina sequencing; insert size about 350bp) [14]. Illumina sequencing libraries were constructed according to the manufacturer's protocols. Paired-end (150bp x 2) sequencing was performed for all the samples using Illumina HiSeq4000 sequencer. 


\section{Transcriptome assembly and functional annotation}

Raw single-cell RNA-Seq reads were filtered by the fastq_quality_filter (-q 20, -p 80) in the FASTX-Toolkit [15]. We first de novo assembled a reference transcriptome by merging all eight sets of RNA-Seq data using Trinity [16] with default parameters. The assembled transcript fragments served as reference transcriptome sequences. Predicted protein sequences (note that some were partial sequences of a protein) were obtained by translating the six possible reading frames of the assembled transcripts using the TransDecoder [16]. All predicated (or partial) protein sequences were integrated into a database that was used for protein identification from mass spectrometry data. We used InterProScan-5.19-58.0 [17] for functional annotation of the protein sequences.

\section{Analysis of differentially expressed genes}

Filtered reads were mapped back to the assembled transcriptome, and the read count for each gene was obtained using the RSEM output which integrated in Trinity with default parameters [16]. We chose the number of FPKM to represent the gene expression abundance. DEGs were defined as those with an FDR p-value $\mathbb{X} 0.001$ and $\log _{2}{ }^{\mid F C l} \geq 2$ expression (4-FC). Gene ontology (GO) enrichment analysis provided all of the GO terms that were significantly enriched in DEGs using BinGO [18], and we filtered the DEGs that corresponded to biological functions.

\section{Protein extraction}

OAs were harvested, washed three times with cold ultra-pure water (Milli-Q, Millipore), mixed with the NuPAGE LDS sample buffter (Invitrogen, USA), and sonicated at $70^{\circ} \mathrm{C}$ for $10 \mathrm{~min}$. Protein were then separated by NuPAGE gel electrophoresis, followed by silver staining.

\section{Mass spectrometry}

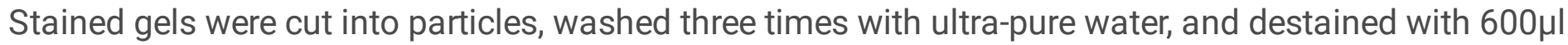
Silver Out butter at room temperature, with shaking. Proteins were then digested overnight with $1 \mu \mathrm{g}$ trypsin at $37^{\circ} \mathrm{C}$. After trypsin digestion, the peptides were desalted by passing through a Self-packed RP $\mathrm{C}_{18}$ solid phase extraction column, acidified by adding $15 \mu$ l loading buffers $(0.1 \%$ formic acid and $3 \%$ acetonitrile), and analyzed by LC-MS/MS (ekspert nanoLC; AB Sciex TripleTOF 5600-plus, USA).

\section{Protein identification and quantification}

ProteinPilot software version 5.0.1 [19] was used to identify and quantify OA proteins. For protein identification and quantification, unique peptides were used to search the predicted protein sequence database (derived from the assembled transcriptome) with additional filters: for protein identification, a 
significance threshold of $\mathrm{p} \leq 0.05$ (95\% confidence) was used; and for protein quantitation, unique peptides were set at $\geq 1$.

\section{Abbreviations}

OA: oral apparatus; RNA-Seq: RNA-sequencing; CaM: calmodulin; ATPase: adenosine triphosphatase; GTPase: guanosine triphosphatase; VPS4: vacuolar protein sorting 4; EF-1a: translation elongation factor 1-a; Hsp: heat shock protein; FC: fold change; DEGs: differentially expressed genes; FPKM: fragments per kilo base of transcript sequence per million base pairs sequenced; IFT: intraflagellar transport; MSM: Modified Stentor Medium; SSU: small subunit; GO: gene ontology.

\section{Declarations}

\section{Ethics approval and consent to participate}

Not applicable.

\section{Consent for publication}

Not applicable.

\section{Competing interests}

The authors declare that they have no competing interests.

\section{Funding}

This project was supported by grants from National Natural Science Foundation of China (31525021) to WM, National Natural Science Foundation of China (31672281 and 31872221) to JX, Youth Innovation Promotion Association of the Chinese Academy of Sciences to JX.

\section{Authors' contributions}

WM, JX, CJ, WY and WW conceived the work. WW, JX wrote the manuscript. All authors have approved the final version of the manuscript.

\section{References}

1. Tartar V. The biology of Stentor. Pergammon press. Oxford. 1961. 
2. Slabodnick MM, Ruby JG, Dunn JG, Feldman JL, DeRisi JL, Marshall WF. The kinase regulator Mob1 acts as a patterning protein for Stentor morphogenesis. PLoS Biol. 2014;12:1-12.

3. Gruber A. Ueber künstliche teilung bei infusorien. Ibid. 1885;4:717-22.

4. Gruber A. Ueber künstliche teilung bei infusorien (II). Ibid. 1885;5:137-41.

5. Balbiani EG. Recherches expérimentales sur la mérotomie des infusoires ciliés. Contribution a I' étude du röle du noyau cellulaire. Rev. Suisse Zool. 1889;5:1-72.

6. Balbiani EG. Sur la formation des monstres doubles chez les Infusoires. J. de l'Anat u. de la Physiol. 1891;27:169-96.

7. Paulin JJ, Bussey J. Oral regeneration in ciliate Stentor coeruleus: a scanning and transmission electron optical study. J. Protozool. 1971;18:201-13.

8. Neviackas JA, Margulis L. The effect of colchicine on regenerating membranellar cilia in Stentor coeruleus. J. Protozool. 1969;16;165-71.

9. Maloney MS, McDaniel WS, Locknar SA, Torlina HM. Identification and localization of a protein immunologically related to caltractin (centrin) in the myonemes and membranelles of the heterotrich ciliate Stentor coeruleus. J. Eukaryotic Microbiol. 2005;52:328-38.

10. Tartar V. Reactions of Stentor coeruleus to certain substances added to the medium. Exp. Cell Res. 1957;13:317-32.

11. Sood P, McGillivary R, Marshall WF. The transcriptional program of regeneration in the giant single cell, Stentor coeruleus. BioRxiv, Cell Biol. 2017. (peer-reviewed).

12. Slabodnick MM, Ruby JG, Reiff SB, Swart EC, Gosai S, Prabakaran S, et al. The macronuclear genome of Stentor coeruleus reveals tiny introns in a giant Cell. Curr. Biol. 2017;27:569-75.

13. Burchill BR. Synthesis of RNA and protein in relation to oral regeneration in ciliate Stentor coeruleus. J. Exp. Zool. 1968;167:427-38.

14. Picelli S, Björklund AK, Faridani OR, Sagasser S, Winberg G, Sandberg R. Smart-seq2 for sensitive full-length transcriptome profiling in single cells. Nat. Methods. 2013;10:1096-98.

15. FASTX-Toolkit. http://hannonlab.cshl.edu/fastx_toolkit/.

16. Grabherr MG, Haas BJ, Yassour M, Levin JZ, Thompson DA, Amit I, et al. Full-length transcriptome assembly from RNA-Seq data without a reference genome. Nat. Biotechnol. 2011;29:644-52.

17. Jones P, Binns D, Chang HY, Fraser M, Li WZ, McAnulla C, et al. InterProScan 5: genome-scale protein function classification. Bioinformatics. 2014;30:1236-40.

18. Maere S, Heymans K, Kuiper M. BiNGO: a Cytoscape plugin to assess overrepresentation of Gene Ontology categories in Biological Networks. 
Bioinformatics. 2005;21:3448-9.

19. ProteinPilot (TM) Software. https://sciex.com/products/software/proteinpilot-software.

20. Structure of Mitochondria.

https://www.ruf.rice.edu/ bioslabs/studies/mitochondria/mitotheory.html.

21. Cilia and Flagella-Structure and Functions. https://microbenotes.com/cilia-and-flagellastructure-and-functions/.

22. Wolfe J. Structural analysis of basal bodies of the isolated oral apparatus of Tetrahymena pyriformis. J. Cell Sci. 1970;6:679-700.

23. Gavin RH. The oral apparatus of Tetrahymena. V. Oral apparatus polypeptides and their distribution. J. Cell Sci. 1980;44:317-33.

24. Williams NE, Nelsen EM. HSP70 and HSP90 homologs are associated with tubulin in hetero-oligomeric complexes, cilia and the cortex of Tetrahymena. J. Cell Sci. 1997;110:1665-72.

25. Takeda T, Yoshihama I, Numata O. Identification of Tetrahymena hsp60 as a 14-nm filament protein/citrate synthase-binding protein and its possible involvement in the oral apparatus formation. Genes Cells. 2001;6:139-49.

26. Casano C, Gianguzza F, Roccheri MC, Giorgi DR, Maenza L, Ragusa MA. Hsp40 is involved in cilia regeneration in sea urchin embryos. J. Histochem. Cytochem. 2003;51:1581-7.

27. Stephens RE, Lemieux NA. Molecular chaperones in cilia and flagella: implications for protein turnover. Cell Motil. Cytoskeleton. 1999;44:274-83.

28. Satouh Y, Padma P, Toda T, Satoh N, Ide H, Inaba K. Molecular characterization of radial spoke subcomplex containing radial spoke protein 3 and heat shock protein 40 in sperm flagella of the ascidian Ciona intestinalis. Mol. Biol. Cell. 2005;16:626-36.

29. Yang C, Owen HA, Yang PF. Dimeric heat shock protein 40 binds radial spokes for generating coupled power strokes and recovery strokes of 9+2 flagella. J. Cell Biol. 2008;180:403-15.

30. Brown CR, Doxsey SJ, Hong-Brown LQ, Martin RL, Welch WJ. Molecular chaperones and the centrosome. A role for TCP-1 in microtubule nucleation. J. Biol. Chem. 1996;271:824-32.

31. Gonda K, Komatsu M, Numata O. Calmodulin and $\mathrm{Ca}^{2+} /$ calmodulin-binding proteins are involved in Tetrahymena thermophila phagocytosis. Cell Struct. Funct. 2000;25:243-51.

32. Gross SR, Kinzy TG. Translation elongation factor 1A is essential for regulation of the actin cytoskeleton and cell morphology. Nat. Struct. Mol. Biol. 2005;12:772-8.

33. Rasmussen C, Wiebe C. Cloning of a Schizosaccharomyces pombe homologue of elongation factor 1 alpha by two-hybrid selection of calmodulin-binding proteins. 
Biochem. Cell Biol. 1999;77:421-30.

34. Grainger JM, Chalker DL. VPS4-1 demonstrates dual involvement in vesicle formation and programmed nuclear death (PND) in T. thermophila. Washington University, May 04, 2015.

35. Goel R, Chalker D. Ttherm_ 0532680 shows basal body localization. Washington University, May 06, 2013.

36. Jacobs ME, DeSouza LV, Samaranayake H, Pearlman R.E, Siu KWM, Klobutcher LA. The Tetrahymena thermophila phagosome proteome. Eukaryotic Cell. 2006;5:19902000.

37. Turkewitz AP, Bright LJ. A Rab-based view of membrane traffic in the ciliate Tetrahymena thermophila. Small GTPases. 2011;2:222-6.

38. Käll L, Krogh A, Sonnhammer ELL. A combined transmembrane topology and signal peptide prediction method. J. Mol. Biol. 2004;338:1027-36.

39. Krogh A, Larsson B, von Heijne G, Sonnhammer ELL. Predicting transmembrane protein topology with a hidden Markov model: application to complete genomes. J. Mol. Biol. 2001;305:567-80.

40. Kilburn CL, Pearson CG, Romijn EP, Meehl JB, Giddings THJr, Culver BP, et al. New Tetrahymena basal body protein components identify basal body domain structure. J. Cell Biol. 2007;178:905-12.

41. Laligne C, Klotz C, de Loubresse NG, Lemullois M, Hori M, Laurent FX, et al. Bug22p, a conserved centrosomal/ciliary protein also present in higher plants, is required for an effective ciliary stroke in Paramecium. Eukaryotic Cell. 2010;9:645-55.

42. Yanagisawa HA, Mathis G, Oda T, Hirono M, Richey EA, Ishikawa H, et al. FAP20 is an inner junction protein of doublet microtubules essential for both the planar asymmetrical waveform and stability of flagella in Chlamydomonas. Mol. Biol. Cell. 2014;25:472-1483.

43. Maia TM, Gogendeau D, Pennetier C, Janke C, Basto R. Bug22 influences cilium morphology and the post-translational modification of ciliary microtubules. Biol. Open. 2014;3:138-51.

44. Sun DM, Leung CL, Liem RKH. Characterization of the microtubule binding domain of microtubule actin crosslinking factor (MACF): identification of a novel group of microtubule associated proteins. J. Cell Sci. 2001;114:161-72.

45. Kirschner M, Mitchison T. Beyond self-assembly: from microtubules to morphogenesis. Cell. 1986;45:329-42.

46. Bre MH, Redeker V, Quibell M, Darmanaden-Delorme J, Bressac C, Cosson J, et al. Axonemal tubulin polyglycylation probed with two monoclonal antibodies: widespread evolutionary distribution, appearance during spermatozoan maturation and possible function in motility. J. Cell Sci. 1996;109:727-38. 
47. Structures and functions of microtubules.

https://www.ruf.rice.edu/ bioslabs/studies/invertebrates/microtubules.html.

48. Fauréfremiet E, Rouiller C. Microscopie électronique des structures ectoplasmiques chez les ciliés du genre Stentor. C. R. Hebd. Seances Acad. Sci. 1955;241:678-80.

49. Bettencourt-Dias M, Glover DM. Centrosome biogenesis and function: centrosomics brings new understanding. Nat. Rev. Mol. Cell Biol. 2007;8:451-63.

50. Follit JA, Tuft RA, Fogarty KE, Pazour GJ. The intraflagellar transport protein IFT20 is associated with the Golgi complex and is required for cilia assembly. Mol. Biol. Cell. 2006;17:3781-92.

51. Follit JA, Xu FH, Keady BT, Pazour GJ. Characterization of mouse IFT complex B. Cell Motil. Cytoskeleton. 2009;66:457-68.

52. Ishikawa $\mathrm{H}$, Marshall WF. Ciliogenesis: building the cell's antenna. Nat. Rev. Mol. Cell Biol. 2011;12:222-34.

\section{Tables}

Table 1. Classification of oral apparatus associated proteins in Stentor coeruleus WHEL: proteins previously identified in the oral apparatus of other species.

\begin{tabular}{cc}
\hline Category & Number of genes \\
\hline Molecular chaperone & 40 \\
Calmodulin & 37 \\
ATPase & 24 \\
Microtubule & 22 \\
GTPase & 18 \\
Serine/threonine-protein kinase & 13 \\
Microfilament & 11 \\
Vacuolar protein sorting 4 & 9 \\
Translation elongation factor 1- $\alpha$ & 5 \\
Intermediate filament & 2 \\
\hline
\end{tabular}

Table 2. Classification of proteins associated with the oral apparatus of Stentor coeruleus WHEL: other proteins. 


\begin{tabular}{cc}
\hline Category & Number of genes \\
\hline Structural motif & 75 \\
Proteolysis related proteins & 49 \\
Membrane protein & 33 \\
Transcription/translation & 32 \\
Amino acid metabolism & 27 \\
Signaling & 24 \\
Fatty acid metabolism & 23 \\
Glycolysis/gluconeogenesis & 21 \\
P-loop containing nucleoside triphosphate hydrolase & 15 \\
Ubiquitination & 7 \\
Other & 131 \\
\hline
\end{tabular}

\section{Supplementary Table 2. Significantly enriched gene ontology classification of transcript} fragments upregulated in at least one time point during oral apparatus regeneration in Stentor coeruleus WHEL.

\begin{tabular}{cc}
\hline GO classification & Number of genes \\
\hline Protein amino acid phosphorylation & 41 \\
Translation & 39 \\
\hline Microtubule-based process & 25 \\
\hline Protein folding & 18 \\
\hline DNA integration & 14 \\
\hline Microtubule-based movement & 12 \\
\hline Regulation of cell cycle & 11 \\
\hline Cell cycle & 10 \\
\hline Negative regulation of biological process & 10 \\
\hline DNA replication & 8 \\
\hline Negative regulation of cellular process & 7 \\
\hline Mitosis & 6 \\
\hline DNA recombination & 5 \\
\hline Regulation of cell growth & 4 \\
\hline Negative regulation of angiogenesis & 3 \\
\hline Protein refolding & 3 \\
\hline Regulation of exit from mitosis & 3 \\
\hline Reproductive process & 3 \\
\hline Response to heat & 3 \\
\hline Skeletal muscle fiber development & 3 \\
\hline S-adenosylmethionine biosynthetic process & 2 \\
\hline Platelet activation & 2 \\
\hline Post-chaperonin tubulin folding pathway & 2 \\
\hline Sensory perception of sound & 2 \\
\hline tRNA 3'-terminal CCA addition & 2 \\
\hline Tubulin complex assembly & 2 \\
\hline
\end{tabular}


Table 3. Functional annotation of 44 upregulated differentially expressed genes encoding oral apparatus associated proteins expressed during regeneration in Stentor coeruleus WHEL. 


\begin{tabular}{|c|c|c|c|}
\hline $\begin{array}{l}\text { Time since shock } \\
\text { (hour) }\end{array}$ & Protein ID & InterProScan annotations & $\begin{array}{c}\log _{2}^{\text {fold }} \\
\text { change }\end{array}$ \\
\hline \multirow[t]{13}{*}{0.5} & SCOERU2943621 & NA & 5.09 \\
\hline & SCOERU7006301 & NA & 7.02 \\
\hline & SCOERU2877401 & NA & 5.50 \\
\hline & SCOERU6679132 & IPR012336:Thioredoxin-like fold & 6.32 \\
\hline & SCOERU6943501 & IPR004345:TB2/DP1/HVA22-related protein & 6.90 \\
\hline & SCOERU2877402 & NA & 5.44 \\
\hline & SCOERU5764801 & IPR001451:Hexapeptide repeat & 5.79 \\
\hline & SCOERU2795601 & $\begin{array}{l}\text { IPR000793:ATPase, F1/V1/A1 complex, alpha/beta subunit, C- } \\
\text { terminal }\end{array}$ & 5.71 \\
\hline & SCOERU5105811 & IPR004000:Actin family & 4.53 \\
\hline & SCOERU2812101 & IPR003172:MD-2-related lipid-recognition domain & 4.75 \\
\hline & SCOERU6988901 & NA & 6.35 \\
\hline & SCOERU5749901 & IPR001806:Small GTPase superfamily & 5.10 \\
\hline & SCOERU3786411 & IPR016161:Aldehyde/histidinol dehydrogenase & 5.67 \\
\hline \multirow[t]{8}{*}{1.5} & SCOERU2968301 & IPR020546:ATPase, F1 complex, delta/epsilon subunit, N-terminal & 3.88 \\
\hline & SCOERU7061601 & NA & 5.60 \\
\hline & SCOERU7009101 & NA & 4.98 \\
\hline & SCOERU5436301 & IPR000297:Peptidyl-prolyl cis-trans isomerase, PpiC-type & 7.07 \\
\hline & SCOERU6787901 & IPR000308:14-3-3 protein & 5.39 \\
\hline & SCOERU2806701 & IPR019956:Ubiquitin & 5.37 \\
\hline & SCOERU3667401 & IPR003000:Sirtuin family & 3.42 \\
\hline & SCOERU5130801 & IPR013766:Thioredoxin domain & 3.56 \\
\hline \multirow[t]{2}{*}{3} & SCOERU6382613 & IPR007714:Cilia/flagella-associated protein 20/WDR90/C3orf67 & 3.72 \\
\hline & SCOERU6954101 & IPR019734:Tetratricopeptide repeat & 3.98 \\
\hline \multirow[t]{5}{*}{4} & SCOERU2800911 & NA & 3.85 \\
\hline & SCOERU4638001 & NA & 5.20 \\
\hline & SCOERU6593301 & IPR004000:Actin family & 7.01 \\
\hline & SCOERU7014001 & NA & 4.05 \\
\hline & SCOERU6797711 & IPR001916: Glycoside hydrolase, family 22 & 4.09 \\
\hline \multirow[t]{9}{*}{6} & SCOERU6902301 & IPR005788:Disulphide isomerase & 4.34 \\
\hline & SCOERU6935001 & NA & 4.23 \\
\hline & SCOERU5237302 & IPR011992:EF-hand domain pair & 4.86 \\
\hline & SCOERU5212701 & IPR001404:Heat shock protein Hsp90 family & 5.72 \\
\hline & SCOERU6079601 & NA & 4.06 \\
\hline & SCOERU2832411 & IPR011992:EF-hand domain pair & 4.25 \\
\hline & SCOERU6109121 & IPR003108:Gas2-related domain & 4.81 \\
\hline & SCOERU5478902 & IPR003108:Gas2-related domain & 4.63 \\
\hline & SCOERU5679902 & IPR011992:EF-hand domain pair & 5.68 \\
\hline \multirow[t]{2}{*}{8} & SCOERU2839501 & IPR011992:EF-hand domain pair & 5.72 \\
\hline & SCOERU5228401 & IPR011992:EF-hand domain pair & 4.14 \\
\hline \multirow[t]{5}{*}{9} & SCOERU6948601 & $\mathrm{NA}$ & 3.87 \\
\hline & SCOERU6991801 & NA & 4.61 \\
\hline & SCOERU5131001 & IPR005018:DOMON domain & 3.61 \\
\hline & SCOERU2821601 & IPR002913:START domain & 3.54 \\
\hline & SCOERU7013301 & IPR004045:Glutathione S-transferase, N-terminal & 5.00 \\
\hline
\end{tabular}

NA, no annotation information. 
Table 4. Functional annotation of 40 downregulated differentially expressed genes encoding oral apparatus associated proteins expressed during regeneration in Stentor coeruleus WHEL.

\begin{tabular}{|c|c|c|c|}
\hline $\begin{array}{l}\text { Time since } \\
\text { shock (hour) }\end{array}$ & Protein ID & InterProScan annotations & $\log _{2}{ }^{\text {fold change }}$ \\
\hline \multirow[t]{28}{*}{0.5} & SCOERU6558001 & IPR001664:Intermediate filament protein & -14.50 \\
\hline & SCOERU6199801 & IPR013126:Heat shock protein 70 family & -16.13 \\
\hline & SCOERU6230702 & IPR001664:Intermediate filament protein & -16.16 \\
\hline & SCOERU6653011 & IPR002423:Chaperonin Cpn60/TCP-1 family & -15.11 \\
\hline & SCOERU6653002 & IPR002423:Chaperonin Cpn60/TCP-1 family & -14.27 \\
\hline & SCOERU3340101 & IPR006140:D-isomer specific 2-hydroxyacid dehydrogenase, & -13.26 \\
\hline & SCOERU6177802 & IPR009014:Transketolase C-terminal/Pyruvate-ferre doxin o & -13.72 \\
\hline & SCOERU6611202 & IPR001404:Heat shock protein Hsp90 family & -7.17 \\
\hline & SCOERU5662301 & IPR004541:Translation elongation factor EFTu/EF1A, bacterial/organelle & -13.69 \\
\hline & SCOERU6825012 & IPR014001:Helicase superfamily 1/2, ATP-binding domain & -4.10 \\
\hline & SCOERU6773301 & IPR004000:Actin family & -5.23 \\
\hline & SCOERU6467901 & IPR000308:14-3-3 protein & -14.57 \\
\hline & SCOERU6490301 & IPR018108:Mitochondrial substrate/solute carrier & -5.54 \\
\hline & SCOERU6807002 & IPR013126:Heat shock protein 70 family & -3.46 \\
\hline & SCOERU6654401 & IPR001557:L-lactate/malate dehydrogenase & -15.06 \\
\hline & SCOERU6525301 & IPR002423:Chaperonin Cpn60/TCP-1 family & -5.49 \\
\hline & SCOERU6348101 & IPR001680:WD40 repeat & -4.24 \\
\hline & SCOERU6661701 & IPR004539:Translation elongation factor EF1A, eukaryotic/archaeal & -4.55 \\
\hline & SCOERU6773311 & IPR004000:Actin family & -4.83 \\
\hline & SCOERU6508701 & IPR001806:Small GTPase superfamily & -5.16 \\
\hline & SCOERU6188202 & IPR000652:Triosephosphate isomerase & -14.55 \\
\hline & SCOERU6728001 & IPR005788:Disulphide isomerase & -14.02 \\
\hline & SCOERU5219902 & IPR000741:Fructose-bisphosphate aldolase, class-I & -14.41 \\
\hline & SCOERU6177301 & IPR020828:Glyceraldehyde 3-phosphate dehydrogenase, NAD( & -6.13 \\
\hline & SCOERU6841701 & IPR000217:Tubulin & -3.79 \\
\hline & SCOERU6823801 & IPR000504:RNA recognition motif domain & -13.80 \\
\hline & SCOERU6214201 & IPR005952:Phosphoglycerate mutase 1 & -14.06 \\
\hline & SCOERU3306301 & IPR001697:Pyruvate kinase & -6.73 \\
\hline \multirow[t]{12}{*}{1.5} & SCOERU3671001 & IPR018108:Mitochondrial substrate/solute carrier & -2.77 \\
\hline & SCOERU5535901 & IPR013126: Heat shock protein 70 family & -6.48 \\
\hline & SCOERU6824901 & IPR001404:Heat shock protein Hsp90 family & -7.31 \\
\hline & SCOERU6273502 & IPR002423:Chaperonin Cpn60/TCP-1 family & -13.77 \\
\hline & SCOERU6088901 & IPR011992:EF-hand domain pair & -13.29 \\
\hline & SCOERU6914701 & IPR001148:Alpha carbonic anhydrase & -2.77 \\
\hline & SCOERU6506211 & IPR005722:ATPase, F1 complex, beta subunit & -14.94 \\
\hline & SCOERU6805001 & IPR000308:14-3-3 protein & -4.97 \\
\hline & SCOERU6455701 & IPR004045:Glutathione S-transferase, N-terminal & -7.35 \\
\hline & SCOERU6841712 & IPR000217:Tubulin & -17.00 \\
\hline & SCOERU6507601 & IPR000217:Tubulin & -6.94 \\
\hline & SCOERU6628602 & IPR001557:L-lactate/malate dehydrogenase & -14.81 \\
\hline
\end{tabular}




\section{Figures}
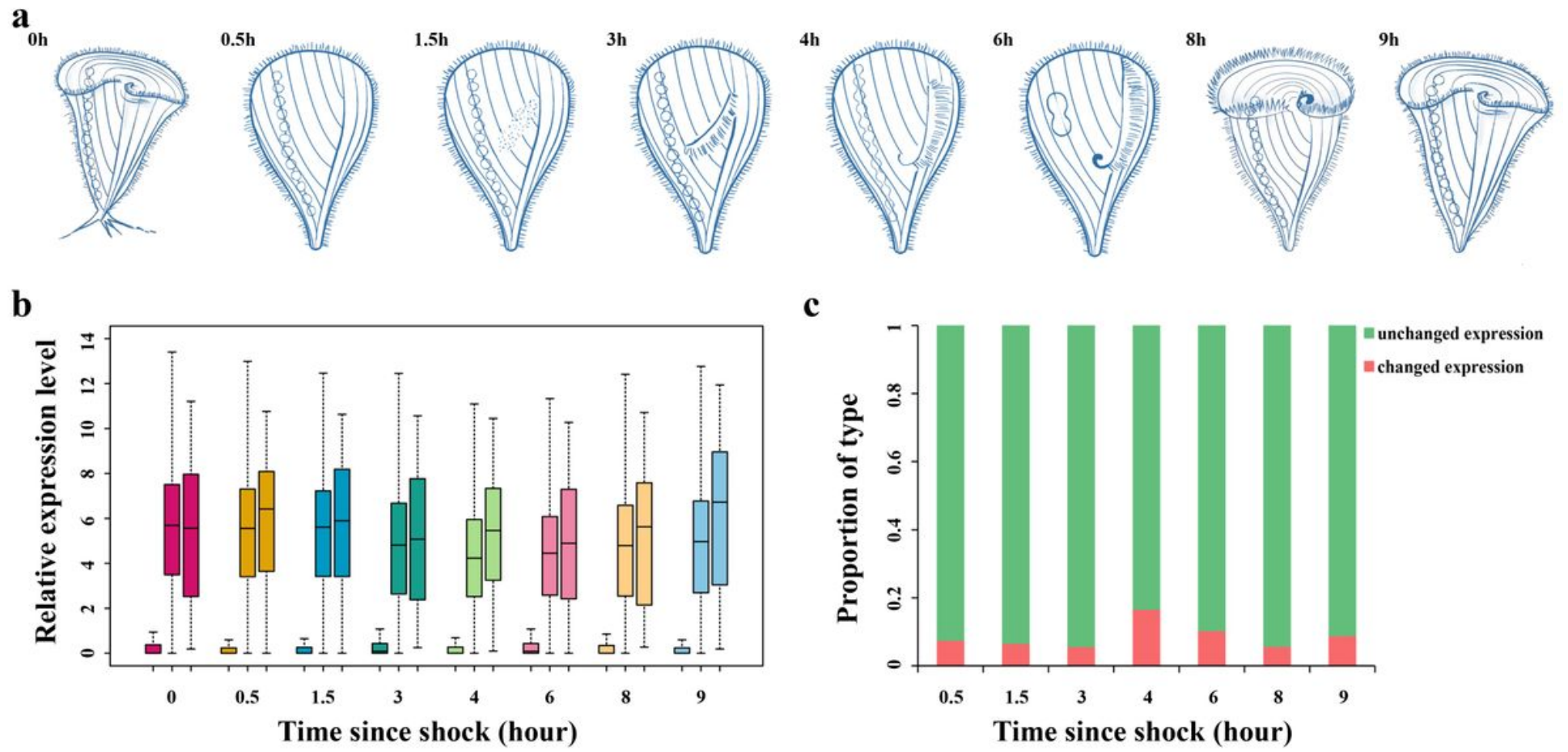

c

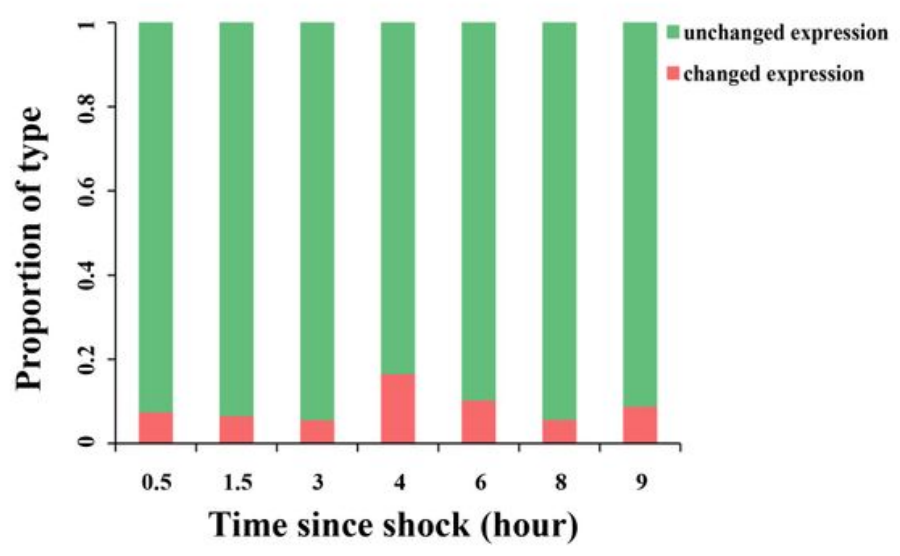

Figure 1

Overall expression patterns of OA-associated proteins during regeneration in Stentor coeruleus WHEL. (a) Morphological events during oral apparatus regeneration in Stentor coeruleus WHEL (based on Sood et al., 2017). Time (in hours) since urea shock is on the upper left. Oh, the normal cell shape before urea shock. $0.5 \mathrm{~h}$, after the OA is shed, the anterior end of the cell is healed. The event marks the start of regeneration. 1.5h, basal bodies have begun to form at the locus of the OA primordium, appearing as a rift across fine striping near area of widest stripes. $3 \mathrm{~h}$, the first cilia of the membranellar band are visible in the OA primordium. 4h, the new membranellar band elongates and extends along the OA primordium. At this stage, the nodes of the macronucleus begin to condense. $6 \mathrm{~h}$, the new OA is completely formed and the macronucleus has fully coalesced. $8 \mathrm{~h}$, the new $\mathrm{OA}$ is fully regenerated. The membranellar band has completely wrapped around the anterior end of the cell and the macronucleus has re-nodulated. $9 \mathrm{~h}$, The cell resumes the normal shape and feeding activity. (b) Comparison of the expression levels of oral apparatus associated genes, ribosomal genes and other transcript fragments during regeneration in 
Stentor coeruleus WHEL. Category of genes at each stage are indicated (left to right: other transcript fragments, oral apparatus genes, ribosomal genes). Relative expression level was calculated using the log2FPKM method. The lines of the whiskers in the box represent median lines. (c) Stacked histogram showing the proportion of oral apparatus associated genes with unchanged and changed expression at each stage of regeneration in Stentor coeruleus WHEL. The same of 809 proteins were analyzed at each stage. $P<0.0001$, calculated using the chi-squared test.

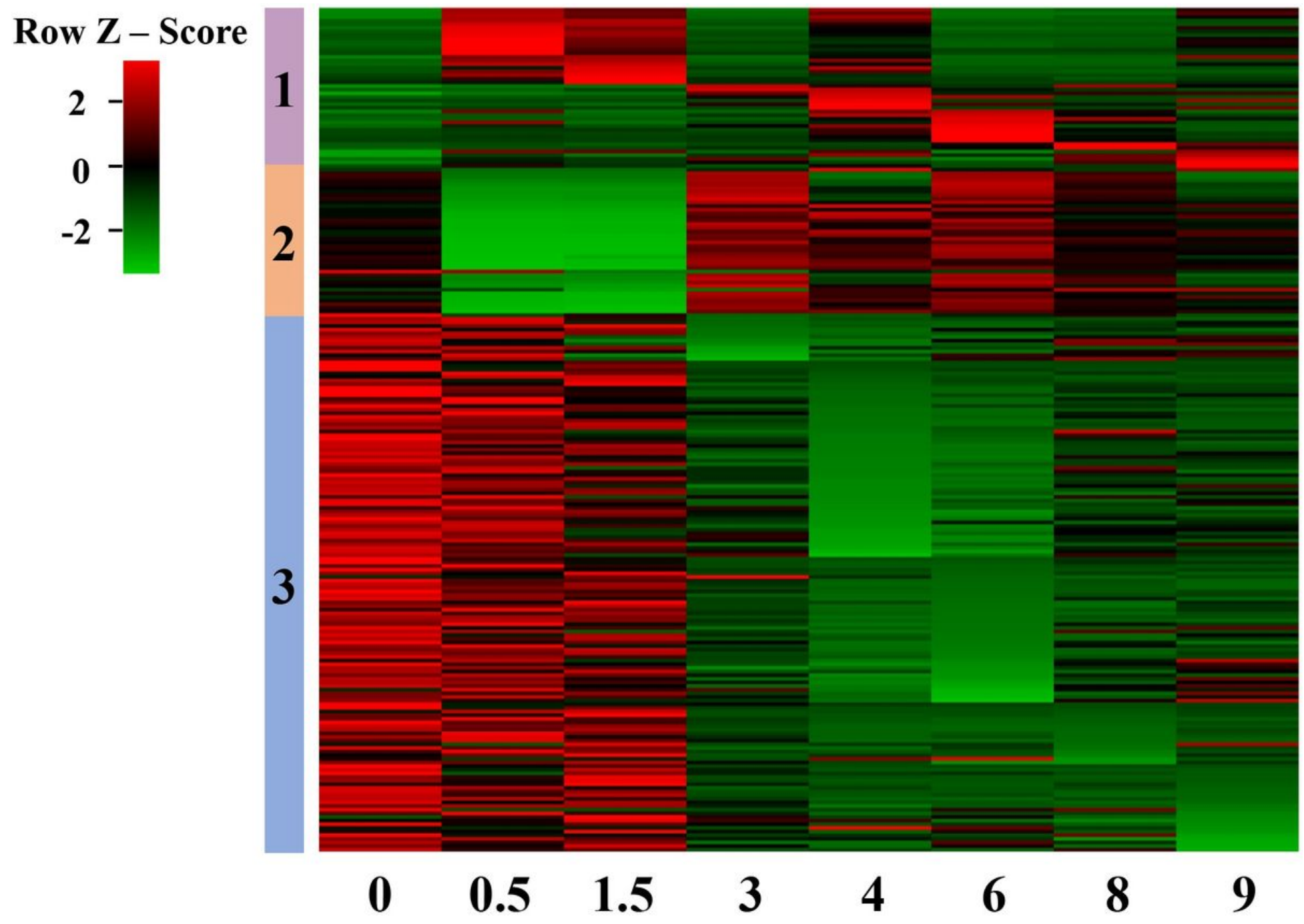

\section{Figure 2}

Gene expression profiles of 232 differentially expressed genes encoding oral apparatus associated proteins during regeneration in in Stentor coeruleus WHEL. Genes were clustered into three groups (indicated by the colored bar on the y-axis). Time (in hours) since urea shock is shown on the x-axis. Group 1 contains all upregulated genes with maximum expression at a single stage of regeneration. Group 2 includes genes that were repressed at the initial stages of regeneration but subsequently increased expression during ciliary biogenesis. Group 3 includes genes that showed rarely changes at the initial stages of regeneration but subsequently downregulated during ciliary biogenesis. (The Z-score is calculated per row). 

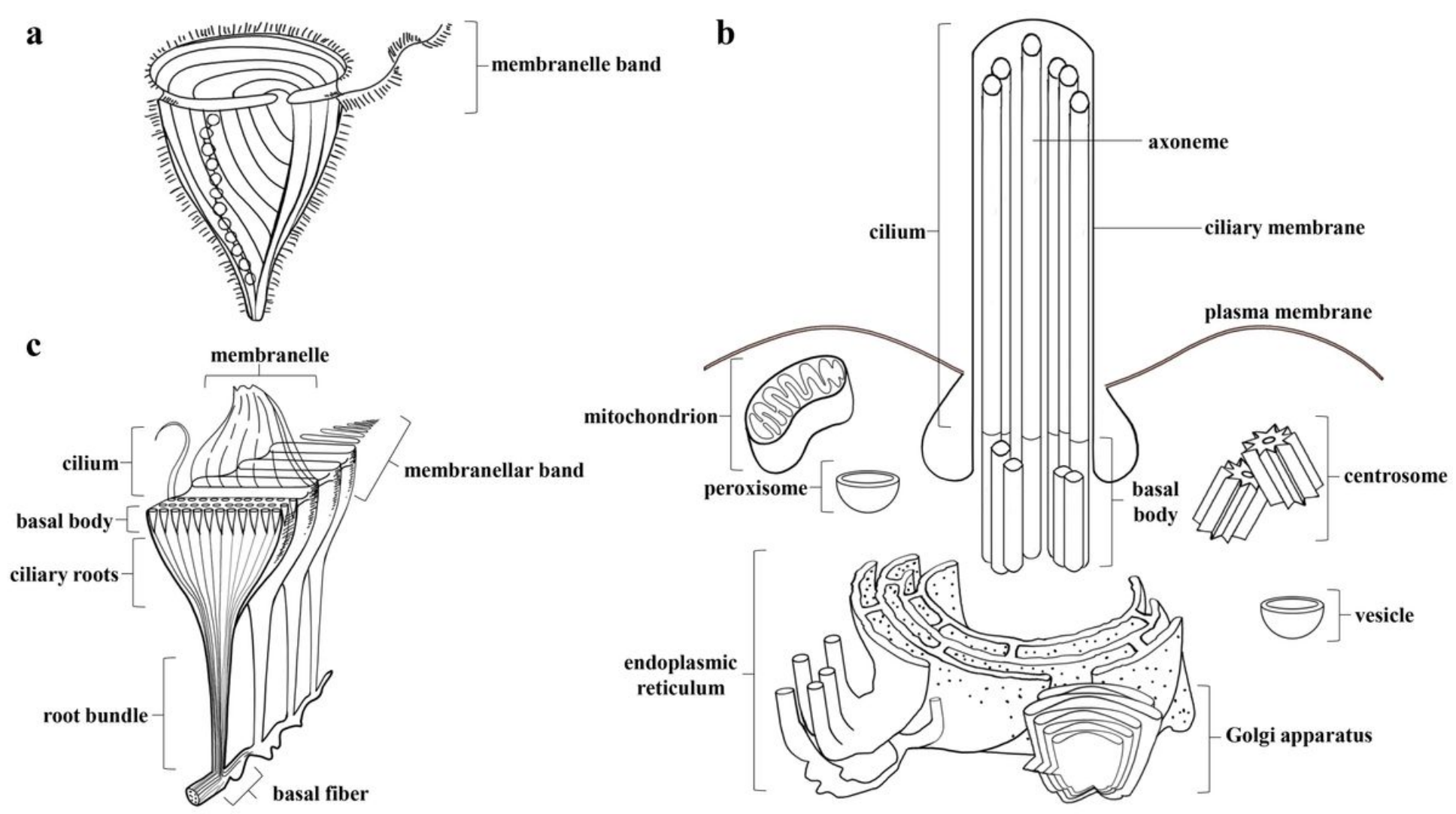

\section{Figure 3}

Hypothetical architecture of oral apparatus in Stentor coeruleus WHEL. (a) The membranellar band is shed during urea shock (based on Sood et al., 2017). (b) Structure of the membranellar band (depicting from Tartar, 1961). (c) Schematic diagram showing the cilium and surrounding subcellular structures.

\section{Oral apparatus}

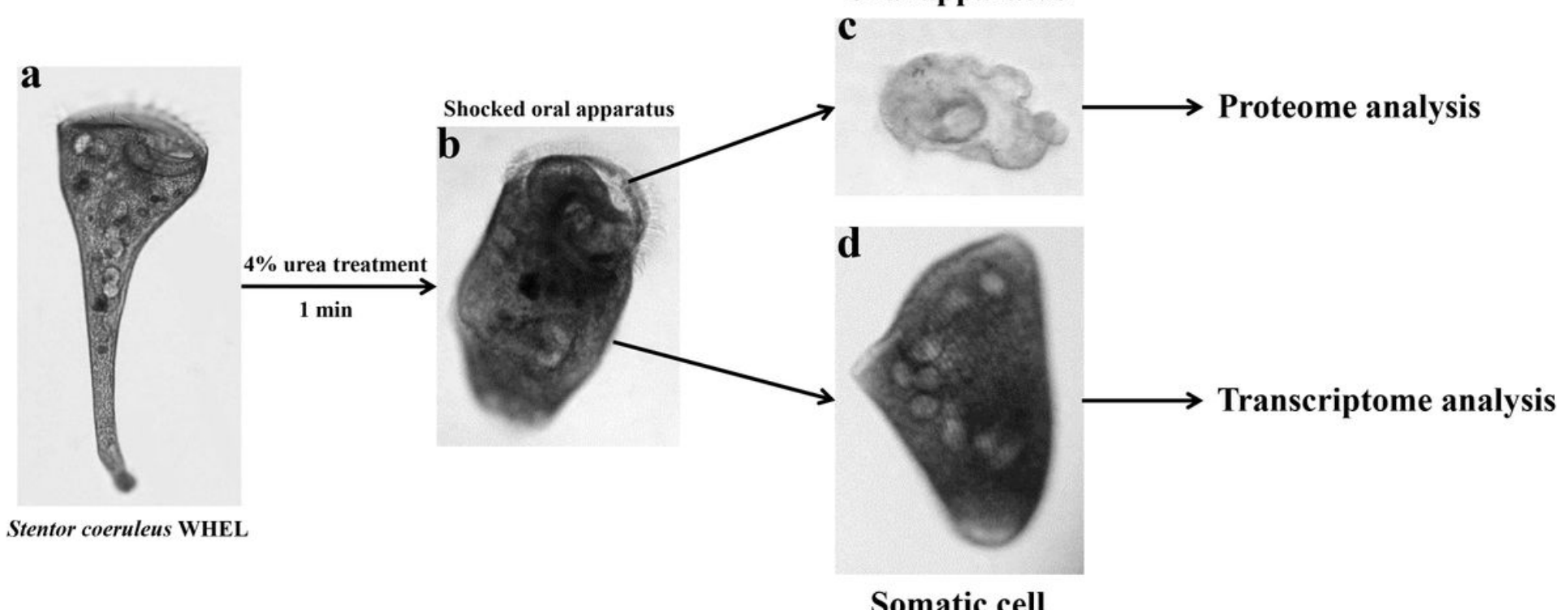

Figure 4 
Overview of regeneration induction and sample collection. (a) Morphological photograph of Stentor coeruleus WHEL. (b) Shedding oral apparatus with $4 \%$ urea treatment for 1 minutes to induce regeneration. (c) Collection of a large number of shedding oral apparatus for proteome analysis. (d) Selecting of single regenerating somatic cells at the different time points for transcriptome analysis.

\section{Supplementary Files}

This is a list of supplementary files associated with this preprint. Click to download.

- SupplementaryTable1.xlsx 